\title{
Pipelle endometrial sampling versus conventional dilatation \& curettage in patients with abnormal uterine bleeding
} Anormal uterin kanamalı hastalarda konvansiyonel dilatasyon ve küretaja karşı
Pipelle endometrial örnekleme

\author{
Ibrahim Anwar Abdelazim ${ }^{1,3}$, Amro Aboelezz ${ }^{2,3}$, Amr Fathy AbdulKareem ${ }^{1,3}$ \\ ${ }^{\prime}$ Department of Obstetrics and Gynecology, Ain Shams University Maternity Hospital, Faculty of Medicine, \\ Ain Shams University, Cairo, Egypt \\ ${ }^{2}$ Department of Obstetrics and Gynecology, Al-azhar University Maternity Hospital, Faculty of Medicine, \\ Al-azhar University, Cairo, Egypt \\ ${ }^{3}$ Department of Obstetrics and Gynecology, Ahmadi Hospital, Ahmadi, Kuwait
}

\section{Abstract}

Objective: This study was designed to compare the diagnostic accuracy of Pipelle endometrial sampling with conventional dilatation \& curettage in patients with abnormal uterine bleeding.

Material and Methods: One hundred and forty patients with abnormal uterine bleeding were included in this comparative study; where endometrial sampling was carried out before cervical dilatation by Pipelle device followed by conventional dilatation \& curettage (D\&C). The histopathology report of the Pipelle sample was compared with that of the dilatation \& curettage sample and the dilatation \& curettage reports were considered as the gold standard.

Results: $100 \%$ of the samples obtained by conventional D\&C, while $97.9 \%$ of the samples obtained by the Pipelle device were adequate for histopathological examination. The histolopathological examination of 140 samples obtained by conventional D\&C revealed proliferative endometrium in 37 specimens, secretory endometrium in 33 specimens, endometrial hyperplasia in 49 specimens ( 45 without atypia \& 4 with atypia), endometritis in 8 specimens, endometrial polyps in 3 specimens and malignant endometrium in 10 specimens.

In this study; the Pipelle device had 100\% sensitivity, 100\% specificity and $100 \%$ accuracy for diagnosing endometrial hyperplasia, endometrial carcinoma, proliferative and secretory endometrium. Also, it had $88.9 \%$ sensitivity, and $99.2 \%$ negative predictive value (NPV) and $99.3 \%$ accuracy for diagnosing endometritis and it had $60 \%$ sensitivity, 89.6\% NPV and $98.6 \%$ accuracy for diagnosing endometrial polyps.

Conclusion: The endometrial sampling using Pipelle is a safe, accurate, cost effective outpatient procedure, which avoids general anesthesia and has a high sensitivity and specificity for detection of endometrial hyperplasia and endometrial malignancy.

(J Turkish-German Gynecol Assoc 2013; 14: 1-5)

Key words: Abnormal, dilatation \& curettage, endometrial sampling, Pipelle, uterine bleeding

Received: 06 November, 2012

Accepted: 12 December, 2012
Özet

Amaç: Bu çalışma anormal uterin kanaması olan hastalarda Pipelle endometriyal örnek alımının tanısal doğruluğunu geleneksel dilatasyon ve küretaj ile karşlaştırmak üzere tasarlandı.

Gereç ve Yöntemler: Bu karşılaştırmalı çalışmaya anormal uterin kanaması olan 140 hasta dâhil edildi; Pipelle aleti ile servikal dilatasyondan önce endometriyal örnek alınmasının ardından geleneksel dilatasyon ve küretaj (D\&C) yapıldı. Pipelle örneğinin histopatoloji raporu dilatasyon ve küretaj örneğininki ile karşılaştırıldı ve dilatasyon ve küretaj raporları altın standart olarak kabul edildi.

Bulgular: Geleneksel D\&C ile alınan örneklerin \%100'ü, Pipelle aleti ile alınan örneklerin ise \%97.9'u histopatolojik inceleme için yeterliydi. Geleneksel D\&C ile alınan 140 örneğin histopatolojik incelemesi 37 örnekte proliferatif endometriyum, 33 örnekte sekretuar endometriyum, 49 örnekte endometriyal hiperplazi (45'inde atipi yok ve 4'ünde atipi var), 8 örnekte endometrit, 3 örnekte endometriyal polip ve 10 örnekte malign endometriyum gösterdi.

Bu çalışmada, endometriyal hiperplazi, endometriyal karsinoma, proliferatif ve sekretuar endometriyum tanısında Pipelle aleti; \%100 sensitivite, $\% 100$ spesifisite ve $\% 100$ doğruluğa, ayrıca endometrit tanısında \%88,9 sensitivite, $\% 99.2$ negatif prediktif değer (NPD) ve $\% 99.3$ doğruluğa ve endometriyal polip tanısında $\% 60$ sensitivite, \%89.6 NPD ve \%98.6 doğruluğa sahipti.

Sonuç: Pipelle kullanılarak yapılan endometriyal örnekleme, endometriyal hiperplazi ve endometriyal malignitenin saptanmasında yüksek sensitivite ve spesifisite ile birlikte genel anestezinin yapılmadığı, güvenli, doğru, maliyet etkin bir ayaktan hasta prosedürüdür.

(J Turkish-German Gynecol Assoc 2013; 14: 1-5)

Anahtar kelimeler: Anormal, dilatasyon ve küretaj, endometriyal örnekleme, Pipelle, uterin kanama

Geliş Tarihi: 06 Kasım 2012

Kabul Tarihi: 12 Aralık 2012

\section{Introduction}

Abnormal uterine bleeding is a major gynecological problem, accounting for $33 \%$ of outpatient referrals, including $69 \%$ of referrals in the peri-menopausal and postmenopausal age groups (1). Evaluation of the abnormal uterine bleeding in women $\geq 40$ years or menopausal women is of critical importance to confirm the benign nature of the problem and to

Address for Correspondence: Ibrahim Anwar Abdelazim, Ahmadi Hospital, Kuwait Oil Company (KOC), P.O. Box: 9758, 61008 Ahmadi, Kuwait 
exclude endometrial carcinoma, so that medical or conservative treatment can be offered and unnecessary radical surgery can be avoided (2).

Dilatation \& curettage (D\&C) is the gold standard for endometrial sampling, but in $60 \%$ of cases, less than half of the uterine cavity is curetted, with the added risk of general anesthesia, infection and perforation $(3,4)$. This has led to the advent of new and simple methods for endometrial sampling. Various devices are on the market nowadays, including the Pipelle device $(5,6)$. The Pipelle can be used on an outpatient basis and is cost effective compared with $\mathrm{D \& C}$ (7). However, there are still concerns regarding the adequacy of the sample obtained, nonsampling of focal intrauterine lesions (6). Therefore, this study was designed to compare the diagnostic accuracy of Pipelle endometrial sampling with conventional D\&C in patients with abnormal uterine bleeding.

\section{Material and Methods}

Over one year, patients with abnormal uterine bleeding over 40 years, were included in this comparative study. Detailed clinical assessment of the patients was followed by transvaginal sonography and laboratory investigations ( $\mathrm{CBC}$, coagulation profile, prolactin, thyroid and liver function tests). Patients with local gynecological cause or possibility of pregnancy or history of contraception or endometrial thickness $<4 \mathrm{~mm}$ were excluded from the study. One Hundred and Forty-three patients were included in this study after informed consent and approval of the study protocol by the institute ethics committee. Patients included in this study were euthyroid with normal liver function tests, normal activated partial thromboplastin time (APTT) and normal platelet count. The endometrial sampling was performed by the Pipelle device in the ward prior to premedication ordered by the anesthetist. The Pipelle (Endocurrette, Midvale, Utah, USA) was introduced without performing cervical dilatation and withdrawn outside the uterus with a rotatory movement to get the sample which was labeled as sample A. The patients were then transferred to the operative theatre for $\mathrm{D} \& \mathrm{C}$ and the obtained sample after D\&C was labeled as sample B. Both samples were sent to a pathologist, who was blinded to the methods of sampling and patients' medical history for histopathology assessment. The histopathology reports of the Pipelle sample was compared with that of the D\&C sample and the $\mathrm{D} \& \mathrm{C}$ report was considered as the gold standard.

\section{Results}

Failure of the procedure was inability to introduce the Pipelle without cervical dilatation in three attempts (3 patients were excluded due to failure to introduce the Pipelle through the cervix to get the endometrial sample and the samples were obtained in those patients by $D \& C$ ). After exclusion of those 3 patients, 140 patients with abnormal uterine bleeding were included in this study, the median age of the studied population was 44.5 years and median age of menarche was 13.5 years, while the median parity was 3.5 and median endometrial thickness was $11 \mathrm{~cm}$, Table 1.
The presenting symptoms of the studied cases were; menorrhagia $(n=53)$, polymenorrhagia $(n=37)$, metrorrhagia or irregular bleeding $(n=26)$ and postmenopausal bleeding $(n=24)$. The sample was labeled as inadequate by the histopathologist when no endometrial tissue was present in the specimen sent. $100 \%$ of the samples obtained by D\&C, while $97.9 \%$ of the samples obtained by Pipelle device were adequate for histopathological examination. The histopathological examination of 140 samples obtained by conventional D\&C revealed; proliferative endometrium in 37 specimens, secretory endometrium in 33 specimens, endometrial hyperplasia in 49 specimens, endometritis in 8 specimens, endometrial polyps in 3 specimens and malignant endometrium in 10 specimens (one endometrial intra-epithelial neoplasia (EIN), 5 adenocarcinoma, 2 adenosquamous carcinoma, one endometrial adenosaroma, one mixed mullerian tumour (MMT)), Table 2.

In this study; the Pipelle device had $100 \%$ sensitivity, $100 \%$ specificity and $100 \%$ predictive values for diagnosing endometrial hyperplasia, endometrial carcinoma, proliferative and secretory endometrium, also, it had $88.9 \%$ sensitivity, $100 \%$ specificity, $100 \%$ positive predictive value (PPV) and 99.2\% negative predictive value (NPV) for diagnosing endometritis, while, it had $60 \%$ sensitivity, 100\% specificity, 100\% PPV and 89.6\% NPV for diagnosing endometrial polyps, Table 3.

In this study; the Pipelle device was $100 \%$ accurate for diagnosing endometrial hyperplasia, endometrial carcinoma, proliferative and secretory endometrium, also, it was $99.3 \%$ accurate for diagnosing endometritis and it was $98.6 \%$ accurate for diagnosing endometrial polyps, Table 3.

\section{Discussion}

Endometrial biopsy is an important step in the assessment of abnormal uterine bleeding to rule out endometrial carcinoma, so that medical or conservative surgery can be offered and unnecessary radical surgery can be avoided. Various methods of endometrial sampling are used in practice, including invasive and non-invasive on an inpatient or outpatient basis $(8,9)$.

$\mathrm{D} \& \mathrm{C}$ is an invasive inpatient procedure performed under general anesthesia. Pipelle device is used as outpatient noninvasive method gives adequate endometrial sample in 98\% of cases and the probability of getting an adequate sample increases when central endometrial thickness is more than 5 $\mathrm{mm}(10,11)$, this is why patients with endometrial thickness $<4 \mathrm{~mm}$ were excluded from this study, also, in this study, the samples obtained by Pipelle device were adequate for histopathological examination in $97.9 \%$.

Table 1 . The characteristics of the studied population

\begin{tabular}{|l|c|c|}
\hline Variables & Median & Range \\
\hline Age (years) & 44.5 & $40-49$ \\
\hline Age of menarche (years) & 13.5 & $12-15$ \\
\hline Parity & 3.5 & $1-6$ \\
\hline Endometrial thickness (mm) & 11 & $10-12$ \\
\hline
\end{tabular}


Table 2. The histopathological results of the specimens obtained by conventional dilatation \& curettage (D\&C) and Pipelle device

\begin{tabular}{|l|c|c|}
\hline Histopathological diagnosis & $\begin{array}{c}\text { Histopathological results } \\
\text { of the specimens obtained by } \\
\text { conventional D\&C }\end{array}$ & $\begin{array}{c}\text { Histopathological results of the } \\
\text { specimens obtained by the } \\
\text { Pipelle device }\end{array}$ \\
\hline Proliferative endometrium & 37 & 37 \\
\hline Secretory endometrium & 33 & 45 \\
\hline Endometrial hyperplasia without atypia & 45 & 4 \\
\hline Endometrial hyperplasia with atypia & 4 & $7 *$ \\
\hline Endometritis & 8 & $1 * *$ \\
\hline Endometrial polyp & 3 & 1 \\
\hline Endometrial intraepithelial neoplasia (EIN) & 1 & 5 \\
\hline Adenocarcinoma & 5 & 2 \\
\hline Adenosquamous carcinoma & 2 & 1 \\
\hline Endometrial adenosarcoma & 1 & 1 \\
\hline Mixed Mullerian tumor (MMT) & 1 & \\
\hline$*$ One case of endometritis could not be diagnosed by Pipelle sampling, because the tissue sent was inadequate for histopathological examination \\
** Two cases of endometrial polyps could not be diagnosed by Pipelle sampling, because the tissue sent was inadequate for histopathological examination \\
\hline
\end{tabular}

Table 2. The sensitivity, specificity, predictive values and accuracy of the Pipelle device for diagnosing endometrial histology in patients with abnormal uterine bleeding

\begin{tabular}{|c|c|c|c|c|c|c|}
\hline Variables & $\begin{array}{c}\text { Proliferative } \\
\text { endometrium }\end{array}$ & $\begin{array}{c}\text { Secretory } \\
\text { endometrium }\end{array}$ & $\begin{array}{l}\text { Endometrial } \\
\text { hyperplasia }\end{array}$ & $\begin{array}{c}\text { Endometrial } \\
\text { carcinoma }\end{array}$ & Endometritis & $\begin{array}{c}\text { Endometrial } \\
\text { polyps }\end{array}$ \\
\hline $\begin{array}{l}\text { Sensitivity } \\
=\text { true positive/ } \\
\text { true positive }+ \text { false } \\
\text { negative X } 100\end{array}$ & $100 \%$ & $100 \%$ & $100 \%$ & $100 \%$ & $\begin{array}{c}8 / 8+1 \\
=88.9 \%\end{array}$ & $\begin{array}{l}3 / 3+2 \\
=60 \%\end{array}$ \\
\hline $\begin{array}{l}\text { Specificity } \\
=\text { true negative/ } \\
\text { true negative }+ \\
\text { false positive X } 100\end{array}$ & $100 \%$ & $100 \%$ & $100 \%$ & $100 \%$ & $\begin{array}{c}132 / 132+0 \\
=100 \%\end{array}$ & $\begin{array}{c}137 / 137+0 \\
=100 \%\end{array}$ \\
\hline $\begin{array}{l}\text { PPV } \\
=\text { True positive/ } \\
\text { (True positive }+ \\
\text { false positive) X } 100\end{array}$ & $100 \%$ & $100 \%$ & $100 \%$ & $100 \%$ & $\begin{array}{l}8 / 8+0 \\
=100 \%\end{array}$ & $\begin{array}{l}3 / 3+0 \\
=100 \%\end{array}$ \\
\hline $\begin{array}{l}\text { NPV } \\
=\text { True negative/ } \\
\text { (True negative }+ \\
\text { false negative) X } 100\end{array}$ & $100 \%$ & $100 \%$ & $100 \%$ & $100 \%$ & $\begin{array}{c}132 / 132+1 \\
=99.2 \%\end{array}$ & $\begin{array}{c}137 / 137+2 \\
=89.6 \%\end{array}$ \\
\hline $\begin{array}{l}\text { Accuracy } \\
=\text { True positive }+ \\
\text { true negative/ } \\
\text { (True positive }+ \\
\text { true negative }+ \\
\text { false positive+ } \\
\text { false negative) } \times 100\end{array}$ & $100 \%$ & $100 \%$ & $100 \%$ & $100 \%$ & $\begin{array}{l}140 / 141 \\
=99.3 \%\end{array}$ & $\begin{array}{l}140 / 142 \\
=98.6 \%\end{array}$ \\
\hline
\end{tabular}

Pipelle sampling can be performed without anesthesia or analgesia during routine pelvic examination, in this study; the Pipelle sampling was done in the ward, followed by general anesthesia and D\&C to maintain synchronization during sampling, which is needed during this comparative study.

Many authors concluded that the Pipelle is an accurate and acceptable outpatient sampling technique when compared with D\&C (12-14). In this study; the Pipelle device had 100\% sensitivity, $100 \%$ specificity and $100 \%$ predictive values, also it was $100 \%$ accurate for diagnosing endometrial hyperplasia (with or without atypia) and endometrial carcinoma.

A systematic quantitative review of published medical literature to determine the accuracy of outpatient endometrial biopsy in diagnosing endometrial hyperplasia in women with abnormal 
uterine bleeding was carried by Clark et al. (15). Although, Clark et al. (15) concluded that outpatient endometrial biopsy has modest accuracy in diagnosing endometrial hyperplasia and additional endometrial assessment should be undertaken, especially if symptoms persist or intrauterine structural abnormalities are suspected, Sarwar et al. (16), concluded that the Pipelle had a $100 \%$ sensitivity, $98 \%$ specificity, and $100 \%$ NPV for detection of endometrial hyperplasia and atypia in women with postmenopausal bleeding.

Mechado and colleagues reviewed 1535 reports of endometrial biopsies taken from outpatients using the Cornier Pipelle, in pre- and postmenopausal patients with abnormal vaginal bleeding, to establish the accuracy of endometrial biopsy with the Cornier Pipelle in the diagnosis of endometrial cancer and atypical endometrial hyperplasia. The Cornier Pipelle was $84.2 \%$ sensitive, $99.1 \%$ specific, $96.9 \%$ accurate, with $94.1 \%$ PPV and $93.7 \%$ NPV for detection of endometrial carcinoma and atypical hyperplasia and they concluded that endometrial biopsy taken with the Cornier Pipelle is an accurate method for diagnosis of endometrial cancer and its precursor atypical hyperplasia (17).

Three hundred sixty endometrial cancer patients had preoperative endometrial sampling to evaluate the ability of preoperative endometrial sampling to accurately diagnose high-grade endometrial tumors were included in Gloria et al. (18) study. Gloria et al. (18) concluded that Pipelle endometrial sampling was 93.8\% sensitive for diagnosing low-grade endometrial cancer and it was $99.2 \%$ sensitive for diagnosing high-grade endometrial cancer, also, they concluded that the endometrial sampling with Pipelle is sensitive and accurate for the diagnosis of highgrade endometrial tumors.

A meta-analysis to assess the accuracy of endometrial sampling devices in detection of endometrial carcinoma and atypical hyperplasia was done by Dijkhuijen et al. (19). They concluded that the endometrial biopsy with the Pipelle is superior to other endometrial techniques in detection of endometrial carcinoma and atypical hyperplasia in pre- and postmenopausal women. In this study; the Pipelle had $88.9 \%$ sensitivity, $99.2 \%$ NPV and it was $99.3 \%$ accurate for diagnosing endometritis, also, it had $60 \%$ sensitivity, $89.6 \%$ NPV and it was $98.6 \%$ accurate for diagnosing endometrial polyps, because the accuracy is high when an adequate endometrial sample is obtained and in this study, 3 specimens were reported as inadequate for histopathological evaluation (two of them were diagnosed as endometrial polyps and the other one was diagnosed as endometritis by conventional D\&C).

In this study, in spite of the low sensitivity of the Pipelle device for diagnosing endometritis and endometrial polyps (88.9\% and $60 \%$; respectively), it had a high negative predictive value (99.2\% and 89.6\%; respectively) and high accuracy $(99.3 \%$ \& 98.6\%; respectively), also, Kuruvilla et al. (20), found that the most common histological diagnosis missed with an inadequate endometrial sample was endometrial polyp.

Three patients were excluded from this study due to failure to introduce the Pipelle through the cervix to get the endometrial sample (procedure failure), and the samples were obtained in those patients by $\mathrm{D} \& \mathrm{C}$. No intra-operative or postoperative complications were recorded in this study, this leads to the conclusion that the endometrial sampling using Pipelle could replace the conventional D\&C method of endometrial sampling, because, it is a safe, accurate, cost effective outpatient procedure, avoids general anesthesia with high sensitivity and specificity for detection of endometrial hyperplasia and endometrial carcinoma $(6,21)$.

\section{Conflict of interest}

No conflict of interest was declared by the authors.

\section{References}

1. Goldenstein SR. Modern evaluation of endometrium. Obstet Gynecol 2010; 116: 168-76. [CrossRef]

2. Oehler MK, Rees MC. Menorrhagia: an update. Acta Obstet Gynecol Scand 2003; 82: 405-22. [CrossRef]

3. Telner DE, Jakubovicz D. Approach to diagnosis and management of abnormal uterine bleeding. Can Fam Physicians 2007; 53: 58-64.

4. Clark TJ, Gupta JK. Endometrial sampling of gynaecological pathology. The Obstetrician and Gynaecologist 2002; 4: 169-74. [CrossRef]

5. Vigod SN, Stewart DE. Management of abnormal uterine bleeding by northern, rural and isolated primary care physicians: PART I How are we doing? BMC Women Health 2002; 2: 10. [CrossRef]

6. Brand A, Duduc-Lissoir J, Ehlen TG, Plante M. Diagnosis of endometrial cancer in women in women with abnormal vaginal bleeding. SOGC Clinical Practice Guidelines. J Soc Obst \& Gynae Can 2000; 22: 102-4.

7. Fakhar S, Saeed G, Khan AH, Alam AY. Validity of pipelle endometrial sampling in patients with abnormal uterine bleeding. Ann Saudi Med 2008; 28: 188-91. [CrossRef]

8. Opmeer BC, van Doorn HC, Heintz AP, Burger CW, Bossuyt PM, Mol BW. Improving the existing diagnostic strategy by accounting for characteristics of the women in the diagnostic work up for postmenopausal bleeding. BJOG 2007; 114: 51-8. [CrossRef]

9. Van den Bosch T, Van Schoubroeck D, Domali E, Vergote I, Moerman P, Amant F, et al. A thin and regular endometrium on ultrasound is very unlikely in patients with endometrial malignancy. Ultrasound Obstet Gynecol 2007; 29: 674-9. [CrossRef]

10. Polena V, Mergui JL, Zerat L, Sananes S. The role of Pipelle Mark II sampling in endometrial disease diagnosis. Eur J Obstet Gynecol Reprod Biol 2007; 134: 233-7. [CrossRef]

11. Elsandabesee D, Greenwood P. The performance of Pipelle endometrial sampling in a dedicated postmenopausal bleeding clinic. J Obstet Gynecol 2005; 25: 32-4. [CrossRef]

12. Chaudry A, Javaid M. Clinical usefulness of pipelle endometrial sampling. pak Armed Forces. Med J 2005; 55:122-125.

13. Asif A Z: An acceptable outpatient technique for endometrial biopsy. J College Physician Surg Pak 1999, 9: 14-16.

14. Behnamfar $F$, Khamehchian $T$, Mazoochi $T$, Fahiminejad $T$. Diagnostic value of endometrial sampling with Pipelle suction curettage for identifying endometrial lesions in patients with abnormal uterine bleeding. J Res Med Sci 2004; 3: 21-23.

15. Clark TJ, Mann CH, Shah N, Khan KS, Song F, Gupta JK. Accuracy of outpatient endometrial biopsy in the diagnosis of endometrial hyperplasia. Acta Obstet Gynecol Scand 2001; 80: 784-93. [CrossRef]

16. Ayesha Sarwar and Anwar ul Haque. Types and frequencies of pathologies in endometrial curetting of abnormal uterine bleeding. International $\mathrm{J}$ of Path 2005; 3: 65-70. 
17. Machado F, Moreno J, Carazo M, Leon J, Fiol G, Serna R. Accuracy of endometrial biopsy with the Cornier Pipelle for diagnosis of endometrial cancer and atypical hyperplasia. Eur J Gynaecol Oncol 2003; 24: 279-81.

18. Huang GS, Gebb JS, Einstein MH, Shahabi S, Novetsky AP, Goldberg GL. Accuracy of preoperative endometrial sampling for the detection of high-grade endometrial tumors. Am J Obstet Gynecol 2007; 196: 243.e1-5.

19. Dijkhuizen FP, Mol BW, Brölmann HA, Heintz AP. The accuracy of endometrial sampling in the diagnosis of patients with endome- trial carcinoma and hyperplasia: a meta analysis. Cancer 2000; 89: 1765-72. [CrossRef]

20. A. Kuruvilla, K. Sohan, S. Ramsewak: Outpatient Endometrial Sampling As The Sole Primary Method For Assessing Abnormal Uterine Bleeding In Women Over 35 Years In Trinidad. The Internet Journal of Gynecology and Obstetrics. 2004 Volume 3 Number 1.

21. Bunyavejchevin S, Triratanachat S, Kankeow K, Limpaphayom KK. Pipelle versus fractional curettage for the endometrial sampling in postmenopausal women. J Med Assoc Thai 2001; 84: 326-30. 